\title{
Das TeOrias da InterpretaÇão À TeOria da Decisão: Por uma Perspectiva Realista Acerca DAS INFLUÊNCIAS E CONSTRANGIMENTOS SOBRE A ATIVIDADE JUdicial
}

\author{
Ricardo de Lins e Horta* \\ Alexandre Araújo Costa **
}

1 Introdução: da decisão às teorias da interpretação. 2 Teorias sobre a decisão judicial: panorama do estado da arte. 3 A psicologia da justificação da decisão: articulando descoberta e justificação. 4 Das teorias da interpretação à teoria da decisão. 5 Conclusão. Referências.

\section{RESUMO}

A ideia de que seja possível desenvolver uma metodologia hermenêutica capaz de conduzir a decisões corretas continua sendo um dos elementos centrais dos discursos dogmáticos contemporâneos, especialmente na forma das teorias da argumentação. Em virtude disso, o comportamento judicial configura um elemento secundário no desenvolvimento das teorias tradicionais. As pesquisas descritivas a seu respeito acabaram se inspirando numa peculiar vertente do positivismo, o realismo jurídico, que levou a sério a ideia de que era preciso realizar uma ciência empírica do Direito, capaz de explicar o papel das preferências político-ideológicas, pessoais, entre outras, na decisão judicial. Neste artigo, sustentamos que uma teoria realista da interpretação, que encare o Direito como uma arena decisória, permite que se vislumbre uma teoria da decisão, que integre não só fatores discursivos, mas também estratégicos, sociais e reputacionais da decisão. Para tanto, apresentamos uma série de estudos empíricos, oriundos da Psicologia Cognitiva e Social, da Ciência Política e da Economia Comportamental, que investigam como os fatores extrajurídicos influenciam e constrangem o processo de tomada de decisão judicial. Por fim, com base em teorizações recentes sobre como o raciocínio humano se articula com o processo argumentativo de justificação, defendemos que, do ponto de vista da formulação de uma teoria da decisão judicial, a oposição entre contextos de "descoberta" e "justificação" não mais se sustenta.

* Doutorando em Direito (UnB) e Mestre em Neurociências (UFMG). Pesquisador visitante no grupo Évolution E⿱ Cognition Sociale, da École Normale Supérieure, em Paris (2016-2017).E-mail: <ricardolinshorta@gmail.com>.

** Mestre e Doutor em Direito pela Universidade de Brasília (UnB). Professor da Faculdade de Direito da UnB. Coordenador do Grupo de Pesquisa em Política e Direito (UnB). E-mail: <alexandre.araujo.costa@gmail.com>. 
Palavras-chave: Decisão judicial. Teoria da Argumentação Jurídica. Contexto da descoberta. Fatores extrajurídicos da decisão judicial. Teoria Realista da Interpretação.

\section{INTRODUÇÃO: DA DECISÃO ÀS TEORIAS DA INTERPRETAÇÃO}

Embora a decisão judicial seja um dos temas centrais de todas as abordagens acerca do Direito, foi somente nas últimas décadas que os fenômenos psicológicos envolvidos em tais decisões se tornaram um tema central de investigação. Isso não significa que, em momentos históricos anteriores, tenha passado despercebido o fato de que as decisões judiciais (como quaisquer outras decisões) decorrem de julgamentos fortemente influenciados pelas condições subjetivas do juiz.

Aristóteles, por exemplo, reconhecia que o julgamento adequado era um ato individual que envolvia uma combinação de capacidades intelectivas (sem as quais não seria possível compreender devidamente as consequências das decisões e suas justificativas) e de formação moral (sem as quais seria impossível identificar a solução justa e pesar os interesses em jogo). Os filósofos gregos da Antiguidade não dispunham de uma metalinguagem psicológica que tratasse da cognição como uma atividade cerebral específica, mas Aristóteles desenvolveu categorias voltadas para compreender e avaliar a interferência das condições subjetivas nos processos decisórios, especialmente a noção de “disposição da alma”. Por mais que entendesse relevante formar pessoas capazes de reconhecer intelectualmente uma solução socialmente considerada justa, Aristóteles considerava que a excelência moral consistia em uma disposição da alma para a prática de atos moralmente excelentes. Uma das principais virtudes dessa concepção era a admissão clara de que o desenvolvimento meramente intelectual era incapaz de gerar boas decisões e que, portanto, a sociedade deveria ser capaz de promover uma educação moral das pessoas, para que elas fossem capazes de tomar decisões adequadas tanto no campo ético (do cuidado de si e das relações interpessoais) quanto no campo político. ${ }^{1}$

Tal concepção estava ligada ao profundo ceticismo de Platão e Aristóteles quanto às propostas de organizar a sociedade a partir de um sistema fixo de regras, pois nenhum conjunto prefixado de normas seria capaz de lidar adequadamente com as complexidades da política. Quando uma sociedade atribui valor primordial ao Direito (entendido como conjunto de regras a serem aplicadas) e não à justiça (entendida como um parâmetro finalístico a ser buscado pelas decisões políticas), as decisões jurídicas tendem a ser medidas por uma espécie de fidelidade ao parâmetro normativo, o que exige a formulação de uma teoria da interpretação que regule a conexão entre norma e decisão. A consciente afirmação de que a decisão política não deveria ser reduzida a uma espécie de interpretação normativa conduziu a tradição filosófica de matriz grega a negar centralidade ao pensamento normativista que veio a se tornar hegemônico no pensamento político da modernidade. 
Onde não há uma centralidade da norma, tampouco é cabível a centralidade de uma teoria da interpretação. No caso da tradição filosófica grega, havia uma espécie de teoria da decisão (com outro nome, é claro) que apontava no sentido de que estratégia fundamental para produzir boas decisões não era definir critérios objetivos aplicáveis de forma impessoal, mas formar bons julgadores. Esse esforço exigia uma teoria moral que organizasse o processo decisório, o que conduziu ao desenvolvimento de um discurso que articulasse de forma indissolúvel as noções de ética e política: não é por acaso que Platão descreve a justiça com a metáfora da República e que a Ética a Nicômacos de Aristóteles fosse uma espécie de introdução à Política.

As alterações sociais que estão na base da formação das sociedades modernas evidenciaram os limites estreitos dessa estratégia. Os filósofos gregos pensavam no limite da polis: uma unidade política relativamente pequena, integrada por cerca de 40.000 cidadãos e dotada de uma alta homogeneidade cultural. Essa demografia permitia que um governo central e unitário monitorasse toda a população e tomasse todas as decisões políticas referentes à organização social. Os desafios ligados à organização política de unidades maiores e menos homogêneas envolviam uma camada de complexidade que escapava à teoria grega: a necessidade de estabelecer um governo central que coordenasse uma série de unidades relativamente autônomas de governo. Essa complexidade mais acentuada nos impérios, com sua grande variedade de culturas submetidas ao mesmo governo central, e que exigiam a difícil tarefa de criar estruturas de governos locais que fossem enraizados em seus territórios sem perder a lealdade ao centro de governo. ${ }^{2}$

A centralização governamental é uma estratégia perigosa de governo, pois ela pode conduzir a um gasto demasiado de energia no controle da própria rede de pessoas investidas em funções governamentais. A capacidade de governar territórios amplos e heterogêneos faz que a coesão interna dos governos seja constantemente desafiada: é impossível governar sem alguma forma de descentralização, mas os interesses de cada unidade são dificilmente conciliáveis entre si e com os interesses do governo central. Por mais que grandes unidades centralizadas sejam capazes de gerar exércitos de formidável poder, tais organizações reiteradamente têm sucumbido aos limites da própria capacidade de garantir a unidade do sistema.

Na modernidade, a necessidade de coordenar unidades populacionais maiores e mais diversas foi enfrentada a partir do desenvolvimento de procedimentos impessoais, capazes de gerar resultados adequados independentemente das características pessoais dos governantes. No âmbito do Direito, a tese clássica de que é preciso educar bons julgadores foi substituída pela concepção de que é preciso criar boas leis e aplicá-las de forma impessoal. ${ }^{3}$ Embora as teorias políticas da modernidade tipicamente acentuem o aspecto legislativo do governo como uma das características fundamentais da soberania, devemos também reconhecer que o processo moderno de centralização governamental (que culminou na formação dos Estados nacionais) foi sempre mitigado pelo desenvolvimento de estratégias limitadoras dos poderes 
legislativos do governo, especialmente pelo estabelecimento de uma burocracia judicial relativamente autônoma.

Como indica António Hespanha, ${ }^{4}$ e diversamente do que sugere nossa compreensão usual da ideia de absolutismo, antes de 1800, a lei não apenas era uma fonte de Direito minoritária, mas era também uma fonte subordinada. Os costumes eram a principal fonte invocada nos julgamentos e, ao longo da modernidade, antes que o judiciário se constituísse como um poder político autônomo, foram desenvolvidas várias categorias voltadas a estabelecer parâmetros jurídicos que fossem blindados contra a autoridade governamental: Law of the land, due process, Direito Romano, Direito Natural, princípios gerais de Direito, constituição. Quando o constitucionalismo norte-americano instituiu o judiciário como um dos três "ramos" do governo, já era estabelecida a tradição de que julgamentos adequados deveriam levar em conta parâmetros jurídicos superiores à autoridade dos governos. Quando as constituições passaram a ser consideradas como uma norma jurídica com hierarquia superior ao próprio poder legislativo, a ideia de que o governo se submetia a limites normativos superiores já era bem assentada.

No contexto de uma burocracia judicial cuja autoridade se fundamentava no fato de que eles deveriam ser meros intérpretes de textos normativos dotados de uma autoridade própria, nada mais natural do que a tentativa de descrever as decisões judiciais como processos de interpretação adequada do Direito. ${ }^{5} \mathrm{Na}$ mitologia política da modernidade, as decisões legislativas precisavam ser descritas como expressões da soberania do povo e as decisões judiciais precisavam ser descritas como aplicações adequadas das normas vigentes. $\mathrm{O}$ governo não poderia se apresentar como governo, pois o mito fundante da modernidade política é a ausência de cisão entre governantes e governados: o povo se autogoverna com base em uma noção idealizada de representação, e suas decisões devem ser impostas por meio de procedimentos impessoais de interpretação.

As grandes escolas modernas de hermenêutica foram desenvolvidas nesse contexto de poderes judiciários autônomos que justificavam sua autoridade pelo seu caráter impessoal e que buscavam garantir essa objetividade por meio de discursos dogmáticos, ou seja, por teorias normativas da interpretação que tinham como função primordial oferecer diretrizes capazes de organizar os processos de tomada de decisão e, com isso, contribuir para que o sistema de justiça realizasse as suas funções políticas. Essas teorias normativas evidentemente não eram calcadas em uma descrição realista dos processos efetivos de tomada de decisão, mas em uma descrição idealizada, comprometida com a caracterização de tais processos como manifestações de procedimentos técnicos determinados.

A característica radicalmente moderna de tais teorias está em sua pretensão de oferecer critérios hermenêuticos que possam ser manejados de modo impessoal e cuja utilização conduza a decisões corretas, independentemente de quem seja o julgador. Não se trata apenas de uma perspectiva que não valoriza os elementos psicológicos da decisão, mas de uma 
concepção voltada justamente a proporcionar julgamentos blindados contra esses elementos, cuja única função teórica passa a ser a de um obstáculo a ser superado. A receita para superar esses obstáculos estava em uma concentração na justificação das decisões: a legitimidade de uma decisão não deveria ser fundamentada nas características pessoais dos julgadores, nem nos resultados que ela tenderia a realizar, mas apenas nas razões apontadas para justificar que a decisão era efetivamente uma aplicação adequada dos mandamentos legais.

A ideia de que era possível desenvolver uma metodologia hermenêutica capaz de conduzir a decisões corretas, por mais que seja contrária a todas as nossas intuições relativas ao comportamento individual dos juízes, continua sendo um dos elementos centrais dos discursos dogmáticos contemporâneos. A resiliência dessa concepção é especialmente notável quando consideramos que a teoria tradicional da interpretação foi submetida a uma série de críticas muito severas às idealizações da dogmática jurídica. Todavia, quando observamos com cuidado essas críticas, notamos que existe muito mais um debate acerca de qual seria a metodologia adequada do que acerca da viabilidade de desenvolver uma tal metodologia. A ideia de que seria possível desenvolver um algoritmo interpretativo fixo tem poucos adeptos nos dias de hoje, mas a pretensão original sobreviveu de maneiras mais leves, especialmente na forma das teorias da argumentação.

As teorias da argumentação jurídica, formuladas especialmente nas décadas de 1970 e 1980, podem ser lidas como uma resposta às críticas que foram dirigidas à teoria tradicional pelas teorias positivistas calcadas nos desenvolvimentos contemporâneos da filosofia da linguagem. No início do século XX, várias teorias apontaram o caráter idealista das hermenêuticas dogmáticas e indicaram que uma visão realista dos processos decisórios deveria reconhecer que, em grande medida, as decisões judiciais eram manifestações de preferências políticas. A textura aberta das normas e a inviabilidade de justificar racionalmente os processos decisórios foram apontados por positivistas, como Kelsen e Hart, por realistas, como Alf Ross, e por hermenêuticos, como Hans-Georg Gadamer. A teoria da interpretação de Kelsen é especialmente reveladora dessa crítica: deveríamos ser capazes de diferenciar os atos de conhecimento por meio dos quais identificamos os potenciais significados de uma norma dos atos de vontade pelos quais escolhemos uma das interpretações possíveis. ${ }^{6}$

Essas teorias dirigiram um ataque poderoso contra as abordagens dogmáticas e provocaram contra-ataques ruidosos, mas com alcance teórico limitado, tais como a teoria da interpretação de Emilio Betti. Todavia, logo ficou claro, também, que as teorias positivistas eram fundadas em uma divisão binária entre racionalidade e irracionalidade que não levava em conta os modos pelos quais as decisões eram efetivamente tomadas. Kelsen e Hart partiram do pressuposto positivista de que, ou uma questão é científica (e pode ser racionalmente respondida), ou ela é política (e sobre ela a ciência deveria silenciar). Portanto, afirmar o caráter político das decisões judiciais significava colocá-las fora do alcance da Ciência do Direito, dado que o positivismo parte do dogma de que não é possível tratar racionalmente 
os juízos de valor. ${ }^{7}$ Ademais, cabe ressaltar que a redução positivista de todo juízo de valor a um ato de vontade implica uma noção de escolha que não se deixa compatibilizar com os desenvolvimentos científicos que buscam compreender os comportamentos com base em elementos psicológicos ou inconscientes.

Uma das primeiras reações mais densas contra essa crítica foi elaborada por Chaïm Perelman, que promoveu um retorno a Aristóteles para analisar empiricamente os discursos de justificação efetivamente utilizados em contextos decisórios. Perelman percebeu que, apesar de inexistirem critérios hermenêuticos fixos nem decisões politicamente neutras, isso não significava que a atividade judicial ocorresse da forma desordenada. Havia uma ordem, mas essa ordem precisava ser medida por categorias que rompessem a distinção binária entre um campo racional completamente definido e um campo irracional completamente ilógico. A resposta encontrada por Perelman foi fecunda: havia uma lógica jurídica, que não seguia padrões da lógica formal, mas que tinha suas próprias formas de estabelecer a validade dos argumentos. ${ }^{8}$ Esse foi o pontapé inicial para um giro argumentativo nas teorias hermenêuticas do direito: em vez de se dedicarem ao objetivo impossível de estabelecer critérios hermenêuticos racionais capazes de gerar interpretações corretas, deveria ser possível avaliar os argumentos utilizados (e não o seu resultado): o critério de validade das decisões não deveria estar em sua correspondência com o verdadeiro sentido da lei, mas no fato de a decisão ser tomada a partir de uma argumentação juridicamente razoável.

Esse giro procedimental incorporava alguns elementos do giro pragmático da filosofia da linguagem, especialmente a noção de que as funções da linguagem deveriam ser percebidas no modo como elas contribuem para a articulação efetiva dos comportamentos das pessoas (dimensão pragmática), e não na medida em que elas portam significados verdadeiros (dimensão semântica). As variadas teorias da argumentação tiveram bastante sucesso em sua tentativa de estabelecer critérios de razoabilidade capazes de medir a adequação jurídica dos discursos de justificação. Todavia, os limites dessas teorias logo se tornaram claros também: elas tendem a se concentrar naquilo que os juízes dizem (julgando a validade jurídica a partir da consistência argumentativa), quando a crítica fundamental dos positivistas do início do século XX era que os discursos judiciais não correspondiam ao que os juízes efetivamente fazem. Enquanto o realismo dos positivistas exigia teorias capazes de descrever adequadamente o comportamento dos juízes, esclarecendo o modo pelo qual eles decidem, as teorias da argumentação se concentraram em renovar a dogmática, proporcionando critérios normativos para orientar a prática judicial.

Essa narrativa sugere que a ausência de uma teoria da decisão jurídica fundada em estudos empíricos acerca dos processos efetivos de tomada de decisão é plenamente compatível com as teorias hermenêuticas tradicionais (voltada a elaborar metodologias decisórias baseadas em critérios dogmáticos), com as teorias positivistas (que negavam a possibilidade de uma dogmática racional) e com as teorias da argumentação (que se limitaram a renovar as pretensões dogmáticas do direito). Se hoje existe um grande contingente de pesquisas voltadas a compreender o efetivo 
processo de tomada de decisões, a principal inspiração teórica não está nas teorias citadas, mas em uma peculiar vertente do positivismo, o realismo jurídico. Foi essa a concepção que levou a sério a ideia de que era preciso realizar uma ciência empírica do Direito, capaz de explicar racionalmente o comportamento irracional dos juízes: suas preferências ideológicas, suas concepções de mundo, suas disposições da alma, sua subjetividade, sua classe social, suas ideologias. A ideia de que era possível explicar o fenômeno decisório a partir de conexões causais é muito diversa das tentativas de fixar parâmetros adequados para orientar as decisões judiciais.

Os desenvolvimentos dessa perspectiva não nos conduzem a uma teoria normativa da interpretação (pois os positivistas não deixaram muito espaço para que uma hermenêutica dogmática viesse a ser considerada como uma ciência, ao menos em um sentido diverso da ciência astrológica ou do tarô), nem a uma teoria normativa da argumentação (visto que uma dogmática centrada no processo não tem grandes ganhos com relação a uma dogmática centrada na interpretação verdadeira), mas a uma teoria descritiva da decisão jurídica, capaz de identificar fatores que influenciam os efetivos processos de tomada de decisão.

Cabe ressaltar que os defensores do positivismo, de uma teoria da interpretação ou de uma teoria da argumentação não negam a possibilidade de abordagens científicas voltadas a compreender a psicologia da decisão. Eles simplesmente indicam que esses elementos causais não têm relevância dogmática: para o discurso jurídico, pouco importam os motivos pelos quais uma determinada autoridade enunciou uma decisão, visto que a questão jurídica fundamental (a validade da decisão) é independente dos motivos que influenciaram a decisão. Essas teorias são especialmente compatíveis com a noção clássica, já mencionada por Piero Calamandrei, de que os juízes primeiramente tomam a decisão por meio de uma intuição fulgurante e que somente depois disso desenvolvem uma argumentação voltada a justificar juridicamente a decisão previamente tomada: "às vezes, acontece que o juiz, ao formar a sentença, inverta a ordem normal do silogismo; isto é, encontre antes a conclusão e, depois, as premissas que servem para justificá-la." "Tal percepção, inclusive, permitiu que teóricos vinculados a essa concepção dividissem a atividade decisória em dois "contextos": o "contexto da descoberta", que indica o momento em que o julgador descobre a decisão que considera intuitivamente mais adequada, e o "contexto da justificação", em que ele apresenta publicamente um discurso jurídico voltado a justificar sua decisão intuitiva. Como afirma MacCormick, um dos expoentes da teoria da argumentação:

Logo, a noção essencial é a de dar (o que se entende por, e é apresentado como) boas razões justificatórias em defesa de reivindicações ou decisões. O processo que vale estudar é o processo de argumentação como processo de justificação. (...) o que leva um juiz a considerar vitoriosa uma parte em vez da outra é uma questão totalmente diferente do fato de saber se a reflexão nos revela haver boas razões justificatórias mais favoráveis a uma parte que à outra. ${ }^{10}$

De fato, diversamente do estudo das razões jurídicas invocadas para justificar uma decisão, o estudo empírico dos processos de tomada de decisão não conduz a argumentos com relevância dogmática. Todavia, não parece ter grande utilidade prática essa tentativa 
de reduzir o Direito a um jogo argumentativo e não a uma arena decisória. Se é correta a percepção de que a decisão não é tomada em função da argumentação, também deveríamos reconhecer que, nos processos judiciais, a interferência dos argumentos não deve ser medida em termos de sua consistência argumentativa, mas em termos de sua capacidade de influenciar a decisão. Quando isolamos a participação de um determinado ator, pode até fazer algum sentido distinguir o contexto da descoberta do contexto de justificação. Todavia, quando analisamos conjuntamente a interação dos diversos atores, em que as petições dos advogados influenciam as decisões dos juízes e os votos de um juiz interferem nas decisões dos outros, deixa de fazer sentido a distinção descoberta/justificação, que somente tem potencial heurístico quando descreve um comportamento individual.

Como categoria adequada para analisar as interações coletivas envolvidas nas decisões, essa divisão artificial, voltada especialmente a isolar e valorizar a argumentação jurídica efetivamente manifestada, deixa de ser relevante. Por isso, não obstante a óbvia importância de se zelar por um sistema de Justiça em que as decisões sejam fundamentadas em argumentos válidos e passíveis de debate na esfera pública, é estranho que tanto esforço se tenha dedicado à justificação dogmática das decisões e tão pouco à compreensão dos efetivos processos decisórios. Temos várias teorias interpretativas, algumas teorias da argumentação, mas falta-nos uma teoria da decisão propriamente dita, possivelmente pelas evidentes dificuldades de equilibrar a utilidade dogmática de uma teoria com sua precisão descritiva.

Um argumento frequentemente utilizado na defesa dessa posição é que não é possível "acessar" a mente judicial, e que não há uma metodologia que permita sondar as razões da "descoberta" de uma decisão. Neste artigo, buscamos mostrar que essa objeção não é procedente e que, nos últimos anos, um vasto instrumental vem se desenvolvendo para que a análise de "descoberta" e "justificação" se dê de forma integrada.

A seguir, traçaremos um breve panorama de como a decisão judicial é tratada a partir da Ciência Política, da Economia e da Psicologia, mostrando como os aspectos comportamentais ligados ao contexto da "descoberta" já são extensamente tratados. Em seguida, enfrentaremos o problema de como uma teoria da interpretação poderia ser articulada numa teoria da decisão, com base em teorias recentes sobre justificação e decisões.

\section{TEORIAS SOBRE A DECISÃO JUDICIAL: PANORAMA DO ESTADO DA ARTE}

Para compreender como cientistas políticos e economistas compreendem a decisão judicial, é importante lembrar que, como ciências com pretensões empíricas, o tratamento dispensado ao problema partilha de um pressuposto metodológico que combina uma visão "behaviorista" da decisão - focada no comportamento observável - e baseada no individualismo metodológico, muitas vezes por meio da "teoria da escolha racional". Não é de admirar, 
assim, que, desde o princípio, a ênfase fosse dada não em textos judicias e seus argumentos, mas sobre os resultados das decisões, se procedentes ou não. Passemos em revista essas abordagens sobre a decisão, antes de nos debruçarmos sobre a literatura psicológica.

Desde a década de 1940, cientistas políticos norte-americanos se dedicam ao estudo das influências externas na decisão judicial. Por volta dessa época, os julgamentos da Suprema Corte que, em sua maioria, eram decididos por unanimidade, passaram a ser julgados por um colegiado cada vez mais dividido em linhas ideológicas, progressistas ou conservadoras. ${ }^{11}$ Ademais, por influência do Realismo Jurídico norte-americano, já se tratava com certa naturalidade a ideia de que as preferências político-ideológicas poderiam ter um grande peso na resolução que um magistrado dará à causa - em oposição a uma visão em tese ingênua, "legalista", de que os textos jurídicos seriam o determinante da decisão judicial. ${ }^{12}$

Como boa parte dessa literatura inicialmente se concentrou sobre decisões polêmicas da Suprema Corte, que tratavam de temas moralmente carregados, é compreensível que o partido do Presidente da República que indicou os Ministros do tribunal aparecesse como uma forte variável preditiva de como eles votariam em casos referentes ao direito ao aborto, à discriminação racial e à extensão do porte de armas, por exemplo. A partir de centenas de estudos empíricos, consolidaram-se, assim, os chamados "modelos atitudinais", de acordo com os quais as preferências político-ideológicas seriam determinantes sobre a forma como os juízes decidem. Esses modelos gozaram de grande prestígio na discussão de cientistas políticos e permitiam um olhar razoavelmente preciso sobre a dinâmica dos votos na Suprema Corte.

Os resultados, porém, revelavam-se menos promissores quando os cientistas políticos analisavam os tribunais inferiores e os juízos individuais. Aparentemente, a clivagem ideológica era menos saliente nesses casos. Além disso, uma discussão proposta no início dos anos 1990 por Richard Posner colocava em questão a visão de que juízes nada mais seriam do que grandes ideólogos, utilizando seu cargo para promover políticas de sua preferência.

Para Posner, para compreender as "motivações judiciais", seria preciso primeiro considerar que eles são pessoas comuns e buscam, no seu trabalho, "maximizar" o mesmo que os demais profissionais. Como a remuneração judicial é fixa e prevista em lei, juízes não teriam incentivo para pautar sua atuação por melhores salários, no entanto, poderiam, valendo-se do seu trabalho, buscar melhorar a própria reputação, ganhar prestígio no meio acadêmico e intelectual, ou utilizar formas de reduzir a carga processual, desincumbindo-se mais rapidamente de suas tarefas, para gozar de tempo livre. Posner formulou, assim, uma "teoria da utilidade judicial", bem típica do pensamento dos economistas, para dar tratamento à questão de o que motiva os juízes a decidirem num sentido ou em outro. ${ }^{13}$

Porém, mesmo num país como os Estados Unidos, com larga tradição de estudos nas vertentes realista e atitudinal, esse tipo de afirmação enfrenta suas resistências. Nas provocativas palavras de Frederick Schauer: 
Poucos parlamentares são relutantes em falar sobre seu desejo de serem reeleitos, e poucos dos participantes de processos político-eleitorais têm vergonha em admitir suas ambições. Para um vice-governador ou procurador de Justiça, a perspectiva de se candidatar ao governo do Estado é tida como certa e amplamente discutida (...). Porém, a ambição judicial é um tópico que é raramente discutido e mais raramente ainda admitido, especialmente pelos juízes que a possuem. E para alguém que não é juiz, trazer esse assunto do autointeresse judicial à tona, na companhia de magistrados, é como falar do assunto do preparo de carnes numa convenção de vegetarianos. Juízes federais quase nunca falam publicamente (ou mesmo em privado) do seu desejo de serem promovidos a desembargadores, e desembargadores federais raramente revelam suas aspirações para a Suprema Corte. O que quer que esse silêncio possa mostrar, ele certamente indica que estudar o tópico das ambições judiciais é algo extraordinariamente difícil, e assim, acadêmicos - que por sua vez têm seus próprios incentivos e ambições - provavelmente se afastam do que parece ser uma tarefa intimidadora. ${ }^{14}$

Não obstante essa dificuldade empírica, os acadêmicos norte-americanos que estudam o sistema de Justiça atenderam ao chamado e buscaram formas de aperfeiçoar os modelos de decisão judicial. Em consequência disso, nos últimos quinze anos, uma alternativa ganhou espaço, os chamados "modelos estratégicos". De acordo com esses modelos, as decisões judiciais são influenciadas pelos incentivos que os magistrados têm, devido a seu cargo, como satisfação no trabalho, tempo livre para o lazer, reputação e prestígio, e o prospecto de serem promovidos e a receberem melhores remunerações em tribunais superiores. ${ }^{15}$

Assim, com base nos extensos bancos de dados que contêm decisões da justiça federal norte-americana e aplicando empiricamente o paradigma estratégico, estudiosos norte-americanos têm sugerido, por exemplo, que um juiz não leva em conta apenas sua preferência político-ideológica ao decidir num determinado sentido; ele considera a chance, a priori, de ter sua decisão revertida em tribunais superiores, ou de ser derrotado no colegiado que integra, antes de pautar a causa. ${ }^{16}$ Os resultados também mostram que a tendência padrão de magistrados integrantes de turma é evitar a divergência, seja para não se indispor com seus colegas de trabalho, seja para evitar a tarefa de precisar redigir um longo e fundamentado voto divergente. ${ }^{17}$

Também sob influência da linha do Law E̋ Economics, Nuno Garoupa e Tom Gisnburg desenvolveram uma "teoria econômica" da reputação judicial. Discutindo as estruturas de incentivos do Poder Judiciário, os autores buscam, numa perspectiva do Direito Comparado e com base em dados de dezenas de países, mostrar como o desenho institucional pode favorecer o cultivo de reputações no nível individual ou coletivo. Um juiz bem reputado pode gozar não só da estima dos pares, como também, no meio político e social, receber convites para eventos, tornar-se um autor lido e respeitado no meio acadêmico e ter sua promoção, na carreira, facilitada. Do ponto de vista coletivo, a seu turno, decisões emanadas de judiciários bem reputados parecem mais legítimas aos olhos da população, e 
instituições judiciais respeitadas podem obter mais recursos do orçamento público nacional e influenciar a agenda do seu país. A reputação, assim, pode ser considerada um bem com valor social e econômico. ${ }^{18}$

Analisando a dinâmica entre os tribunais de um mesmo Poder Judiciário, os autores sugerem que, para preservarem sua reputação, cortes constitucionais precisam levar em conta duas audiências externas em suas decisões: uma audiência "política", composta pelos outros Poderes e órgãos de governo; e uma audiência composta pela comunidade jurídica como um todo. Decisões unânimes podem parecer mais legítimas do que decisões não consensuais, e aperfeiçoar a reputação coletiva. Porém, pode ocorrer de diferentes ministros da corte constitucional se preocuparem com audiências externas distintas, de acordo com suas preferências ideológicas ou jurídicas, o que leva à fragmentação, abrindo espaço para a projeção de reputações individuais. ${ }^{19}$

Ao apresentar os modelos estratégicos de decisão judicial produzidos nos Estados Unidos, ao menos duas objeções podem ser vislumbradas: em primeiro lugar, a experiência cotidiana mostra que o conteúdo dos textos jurídicos é, ao contrário do que sugerem, muito importante para o resultado de um processo judicial; em segundo lugar, esses modelos seriam pouco úteis para compreender a realidade brasileira.

A primeira crítica já é respondida pelos próprios estudiosos dos modelos estratégicos. Estudando exaustivamente os dados disponíveis, Lee Epstein e colegas descobriram que as variáveis extrajurídicas são muito importantes para explicar o resultado de decisões da Suprema Corte, mas muito menos relevantes na segunda instância, e menos ainda na primeira. A explicação não é tão surpreendente: o desenho institucional do Poder Judiciário confere ampla discricionariedade à Suprema Corte, mas tribunais inferiores e juízes precisam seguir a jurisprudência, devem cumprir súmulas e geralmente apreciam menos casos difíceis. Como consequência disso, o grau de discricionariedade torna-se maior quanto mais elevada a instância, compreensivelmente maior é o grau de interferência de variáveis extrajurídicas. ${ }^{20}$

A segunda crítica nos parece mais relevante, na medida em que o sistema de Justiça no Brasil passou a ser estudado empiricamente de forma sistemática há pouco mais de vinte anos, especialmente o Supremo Tribunal Federal, e que, após a Reforma do Judiciário, o grau de atuação desse Poder sobre as políticas públicas cresceu significativamente. ${ }^{21}$ Estudos empíricos recentes sugerem que, embora sustente um discurso de que é o guardião dos direitos de cidadania, reforçado por rumorosos casos recentes que trataram de questões como a união homoafetiva, a liberdade de expressão e o direito ao aborto, os números mostram que o STF atua precipuamente em questões de Direito Administrativo, na competência de entes federados e na defesa de interesses corporativos. ${ }^{22}$ Os dados também mostram que as indicações presidenciais podem ter resultados efetivos no resultado de julgamentos polêmicos pelo Supremo Tribunal Federal, como foi o caso do Mensalão. ${ }^{23}$ Além disso, os Ministros daquela Corte possuem poderes de atuação direta no processo político e deles fazem uso 
, como a possibilidade de antecipar posições na imprensa, reter processos indefinidamente por meio do pedido de vista e proferir decisões monocráticas que acabam definindo causas sem que passem pelo colegiado. ${ }^{24} \mathrm{Em}$ suma, as evidências recentes sugerem que modelos estratégicos, devidamente adaptados à nossa configuração institucional, podem produzir resultados interessantes.

Outra literatura que se debruça sobre as influências externas ao Direito na atividade judicante é composta por trabalhos recentes e cada vez mais numerosos, que partem de enfoques cognitivos e comportamentais, oriundos da Psicologia Cognitiva e Social.

Uma caricatura, difundida por muitos, como Ronald Dworkin, ${ }^{25}$ é a de que o ceticismo dos proponentes do Realismo Jurídico quanto aos condicionantes jurídicos da decisão judicial significaria que o Direito dependeria essencialmente daquilo que os juízes "comeram no café da manhã”. Embora pareça absurda, essa afirmação foi objeto de estudo empírico, e, surpreendentemente, os cientistas encontraram um resultado que parece estar de acordo com ela. Analisando mais de mil decisões reais sobre concessão ou não de livramento condicional em Israel, Shai Danziger e colegas descobriram que a variável mais relevante para a soltura ou não do condenado não eram os fatos e os aspectos jurídicos do caso, ou as características pessoais do requerente, mas o horário em que as decisões eram proferidas. No início dos turnos de julgamento, a taxa de concessão de livramento era de 65\% e ia gradualmente decaindo até o fim da sessão. Após a pausa para o lanche, o percentual de decisões procedentes retornava ao patamar de $65 \%$. O provocativo estudo sugeria que o cansaço e a fome poderiam ter consequências concretas na efetivação do direito dos condenados. ${ }^{26}$

Este é apenas um exemplo de uma ampla agenda de pesquisa, que parte dos modelos de julgamento e tomada de decisão consagrados nos últimos 40 anos - sintetizados no livro "Rápido e devagar"27, de Daniel Kahneman, ganhador do prêmio Nobel por seu trabalho em Economia Comportamental - que tratam das "heurísticas" e dos "vieses". Numa breve síntese, esses modelos partem da constatação que, longe de serem agentes racionais que pesam todos os aspectos de um caso antes de decidir como proceder, seres humanos possuem uma racionalidade limitada e tomam decisões em condições de premência de tempo, informação incompleta e recursos mentais escassos. Sendo assim, muitas decisões cotidianas são tomadas com base em palpites e intuições. Em vez de processar exaustivamente toda a informação disponível e optar pelos processos mais complexos e precisos de decisão, humanos se valem de "atalhos cognitivos", as chamadas "heurísticas". Em função disso, o raciocínio humano está sujeito a uma série de desvios sistemáticos em relação ao que se esperaria de uma decisão correta, objetiva e neutra - os chamados "vieses".

Uma das constatações mais consistentes dessa literatura, reproduzida em diversos contextos diferentes, é que mesmo profissionais com alta escolaridade estão sujeitos a vieses cognitivos; e que, mesmo sendo alertados sobre sua existência, estão sujeitos a eles. Uma analogia útil para compreender a onipresença e a certa inevitabilidade dos vieses é compará- 
-los a ilusões de ótica, que também derivam da organização da mente: saber que uma figura é uma ilusão não significa que o observador deixe de vê-la.

Os modelos de heurísticas e vieses parecem se aplicar à decisão judicial, na qual raciocínios automáticos e intuitivos desempenham um papel relevante. Num estudo, pesquisadores ingleses seguiram mais de trezentas decisões reais no período de 4 meses e descobriram que, em julgamentos sobre decisões de fiança, valiam-se de heurísticas, isto é, atalhos cognitivos para reduzir a complexidade do caso e acelerar o processo decisório. Em vez de considerarem a totalidade do conjunto probatório, os magistrados se atinham a uma ou duas informações salientes - a opinião da autoridade policial ou o réu ser primário ou não, por exemplo - ao decidirem se concederiam ou não a fiança. ${ }^{28}$

Juízes não só decidem com heurísticas, como estão sujeitos a vieses cognitivos. Numa sequência de experimentos aplicados em centenas de juízes presentes em conferências para magistrados norte-americanos, Chris Guthrie e colegas reproduziram com eles resultados antes obtidos com amostras de pessoas comuns: apesar de "especialistas em decisão", juízes também se valem de intuições e do "piloto automático" para analisar casos simulados. Ao avaliar se o montante devido numa indenização é justo, magistrados estão sujeitos ao efeito da "ancoragem" - se o valor pedido pelo requerente é maior, a indenização concedida também é maior, e vice-versa. Ou ainda, ao analisarem se um acidente teria resultado de negligência do trabalhador, observou-se a ocorrência do "viés da representatividade", ou seja, a superestimação da probabilidade de ocorrência de um evento saliente, em vez de se basear num cálculo estatístico. ${ }^{29}$

Testando mais diretamente a influência de fatores idealmente irrelevantes para a solução de um caso, em contraste com o direito aplicável, Spamann \& Klöhn recentemente submeteram a 32 juízes norte-americanos um caso decidido pelo Tribunal Penal Internacional para a ex-Iugoslávia. Os magistrados tinham cerca de uma hora para refletir sobre o caso e foram divididos em quatro grupos, em que se variava, de um lado, o sentido de um precedente judicial aplicável ao caso; e, de outro, as características pessoais do requerente que podia exibir uma postura ressentida ou conciliatória. As características pessoais do réu tiveram um impacto estatisticamente mais significante do que a jurisprudência aplicável ao caso - o que pode até ser compreensível, mas certamente não é compatível com uma visão dos textos jurídicos como determinantes da decisão judicial. ${ }^{30}$

Longe de serem exemplos isolados, esses estudos compõem uma literatura crescente, e diversas pesquisas chegam a resultados convergentes. ${ }^{31}$ As consequências de estudos como este para a prática judicial não podem ser subestimadas se o Poder Judiciário analisa os casos a ele submetidos atendo-se apenas a uma parcela saliente das informações, e, de forma enviesada, injustiças podem ser cometidas.

Além de se debruçaram sobre a psicologia da decisão judicial mapeando heurísticas e vieses por meio de métodos e ferramentas oriundos da Psicologia Cognitiva e Social, alguns 
desses estudos se mostraram coerentes com a literatura sobre influências políticas na decisão judicial, apresentada acima.

Dan Kahan e sua equipe buscaram testar se o julgamento sobre os limites da liberdade de expressão dependeria do posicionamento político-ideológico do observador. A tarefa consistia em assistir a um mesmo vídeo, com imagens de um protesto e avaliar a atuação da polícia ao dispersá-lo. Os dizeres das faixas e dos cartazes da manifestação estavam tarjados no vídeo. Dividindo 202 pessoas em dois grupos, os pesquisadores primeiro aplicaram um questionário sobre os posicionamentos políticos dos sujeitos. Em seguida, disseram à metade deles que a manifestação era contra o aborto; e à outra metade, que se tratava de um protesto contra a discriminação direcionada à população LGBT. Conforme concordassem ou não com o conteúdo da manifestação, os participantes tendiam a ver ou não excessos na atuação da polícia ao dispersá-la, ou seja, a extensão do direito à liberdade de expressão dependia, em última análise, à concordância ou não com seu conteúdo político. ${ }^{32}$ Embora a amostra desse estudo não seja de magistrados, é de se questionar se estes não estariam sujeitos às mesmas influências ao autorizarem ou não a atuação de forças policiais em ações de reintegração de posse e de retirada de ocupantes em protestos.

Em outro resultado, Joshua Furgeson e colegas realizaram uma survey com 152 assessores de juízes e descobriram que o método hermenêutico adotado ao solucionar um caso está fortemente correlacionado com as preferências político-ideológicas. Conforme se identificassem como liberais ou conservadores, os assessores tendiam a utilizar uma técnica interpretativa mais extensiva e ativista, de um lado, ou mais restritiva e deferente ao legislador, de outro. Dito de outra forma, a preferência política precedia e condicionava a hermenêutica constitucional a ser adotada na justificação de uma decisão. ${ }^{33}$

A psicologia por trás da política da decisão judicial também emerge no trabalho de Lawrence Baum sobre reputação judicial. Enquanto abordagens baseadas no enfoque econômico, como a de Nuno Garoupa e Tom Ginsburg, tratam genericamente de incentivos institucionais da busca por reputação, Baum aponta para um quadro mais complexo. Como quaisquer pessoas, juízes se preocupariam precipuamente com as opiniões dos seus pares e das pessoas que lhe são caras. Assim, a visão de familiares, amigos, colegas magistrados, do meio acadêmico em que se inserem, das corporações que integram, dos grupos de interesse que apoiam, etc., teriam um peso substancialmente maior do que a das demais pessoas. Baum sugere, assim, que é um equívoco considerar que juízes se preocupam com a opinião pública "em geral" - como qualquer ser humano, eles, na verdade, importam-se com as opiniões de pessoas de seu meio social e cultural, com quem efetivamente convivem. ${ }^{34}$

Esse enfoque permite compreender como tribunais podem decidir contrariamente posições majoritárias na sociedade, mas, geralmente, não decidem contra os pontos de vista da elite jurídica ou socioeconômica de cuja maioria dos seus membros é oriunda. Além disso, permite enriquecer mesmo a análise dos enunciados discursivos de decisões judiciais 
específicas. Como sugere Eileen Braman, a justificação de decisões judiciais se direciona a auditórios específicos, e é, em relação a esses grupos, relevantes para o magistrado, que a argumentação é construída; são esses os grupos que verdadeiramente constrangeriam o universo de possibilidades decisórias. ${ }^{35}$

Todas essas descobertas sobre a ocorrência de influências psicológicas no processo de tomada de decisão judicial também levaram à discussão sobre as formas de reduzir ou mitigar vieses. Entre esses mecanismos, figuram desde a tentativa de conscientizar os julgadores de que estão sujeitos a limitações cognitivas, até isolá-los totalmente de decisões passíveis de influências indevidas. Não trataremos aqui das diversas possibilidades do chamado "desenviesamento", que são objeto de diversos trabalhos específicos recentes. ${ }^{36}$ Porém, destacamos que, se, por um lado, o sistema jurídico já prevê diversos mecanismos para evitar decisões influenciadas por fatores ilegítimos - como os institutos de suspeição e impedimento - por outro, os estudos indicam que eles podem ser insuficientes para corrigir inúmeras injustiças atualmente existentes. ${ }^{37}$ Uma das formas de mitigar vieses seria, inclusive, a polêmica proposta de adotar ferramentas de inteligência artificial na atividade judicante. Com o avanço das novas tecnologias sobre empregos caracterizados pela atividade intelectual, essa é uma discussão que já é realidade. ${ }^{38}$

Diante dos estudos apresentados, sugerimos uma provocação: se já se sabe tanto sobre os aspectos extrajurídicos da decisão judicial, por que se devota tanta atenção a teorias exclusivamente voltadas para o contexto da justificação?

Ao nosso ver, a melhor forma de encaixar esses achados recentes da literatura empírica sobre decisão judicial é acoplar, a uma visão realista da decisão judicial, as influências e constrangimentos extrajurídicos, descrevendo o direito como uma arena decisória em que atores podem agir estrategicamente. ${ }^{39}$ Nesse sentido, é preciso revisitar a distinção tradicional entre processos de descoberta e o contexto da justificação. Para tanto, iniciaremos pelas teorias psicológicas recentes que buscam descrever como se articulam raciocínio e justificação.

\section{A PSICOLOGIA DA JUSTIFICAÇÃO DA DECISÃO: ARTICULANDO DESCOBERTA E JUSTIFICAÇÃO}

A literatura sobre julgamento e tomada de decisão revisada na seção anterior não desconsidera o fato de que, mesmo que as pessoas tomem decisões por motivos irracionais, influenciadas por vieses, ou preferências pessoais, ou emoções, elas, ainda assim, precisam justificar suas escolhas. Seres humanos são animais sociais, que não vivem isoladamente. Pelo contrário, a satisfação e a autoestima pessoal estão sempre intimamente ligadas às relações com os pares e à inserção social do sujeito. Os marcos teóricos que buscam explicar como os processos intuitivos e deliberativos interagem se preocupam em explicar como as pessoas justificam a si próprias e às outras suas decisões. 
No fim dos anos 1970, foi realizado um estudo clássico sobre as opiniões acerca do polêmico tema da pena de morte. Os pesquisadores pediram a 151 estudantes que avaliassem a qualidade metodológica de dois estudos sobre o efeito da pena de morte sobre a prevenção de crimes. A metodologia de ambos era semelhante, mas a qualidade atribuída pelos sujeitos a cada estudo dependia da convicção prévia que eles tinham sobre o tema. Se apoiavam a pena de morte, os resultados empíricos sobre a inexistência de efeito preventivo dessa punição eram postos em dúvida; todavia, se os sujeitos eram contra a pena de morte, desconfiavam dos resultados que apontavam em sentido contrário. Além disso, a assimilação enviesada da informação levava a uma maior polarização - os oponentes da pena de morte ficavam ainda mais convencidos de sua posição inicial, mesmo tendo visto provas em contrário; o mesmo ocorrendo com os defensores, quando confrontados com estudos que contradiziam suas convicções. ${ }^{40}$ Como explicar esses resultados? Por que estamos todos sujeitos, ainda que inconscientemente, a esses vieses?

A chamada "dissonância cognitiva" é um dos fenômenos estudados há mais tempo, sendo mencionado em praticamente todos os manuais introdutórios de Psicologia. Formulado por Leon Festinger no fim dos anos 1950, o modelo propõe que as pessoas buscam o "conforto cognitivo" e se sentem desconfortáveis quando encontram informações que contradizem suas crenças. O estado de "dissonância" entre informações conflitantes precisa ser superado. Para tanto, a mente tenta reduzir a inconsistência, o que geralmente envolve recusar a informação nova que conflita com a crença sedimentada. O mecanismo psicológico da redução da dissonância cognitiva, assim, é o de influência da "motivação" (reduzir a inconsistência) sobre a "cognição" (o processamento de informação). ${ }^{41}$

Próximo do fenômeno da dissonância cognitiva é o do "viés de confirmação", que se refere à tendência, encontrada em diversos contextos experimentais, que os sujeitos têm de buscar ativamente informações que estejam em consonância com suas crenças preconcebidas, e de se sentirem satisfeitos em confirmá-las, ao passo que atribuem pouco peso e evitam se deparar com informações incoerentes com essas mesmas preconcepções. Ou seja, as pessoas tendem a buscar não algo como a "verdade", mas informações que confirmem o que já pensam, e as ajudem a manter as próprias convicções. ${ }^{42}$

Ora, se, do ponto de vista do raciocínio, os seres humanos "enxergam o que desejam ver" ${ }^{\prime 3}$, como é possível que exista debate, e que as pessoas sejam persuadidas a mudar de opinião? O raciocínio é sempre dependente e guiado por motivações e preferências subjacentes? Ora, não é raro que as pessoas abandonem convicções, por mais firmes que sejam, diante de provas em contrário.

Para dar conta desses fenômenos, Ziva Kunda propôs a teoria do "Raciocínio Motivado". Para Kunda, as pessoas podem ter motivações diferentes ao lidarem com um problema, ou ao raciocinarem sobre como solucionar uma questão. A motivação pode ser, conforme o caso, a de buscar uma resposta mais acurada; ou, em vez disso, a de chegar numa conclusão 
específica, coerente com suas preferências. Em alguns contextos, as pessoas estão dispostas a se engajar em um raciocínio deliberado e trabalhoso, admitindo provas em contrário do que pensam, mas elas se dão esse trabalho apenas caso seja efetivamente relevante para si encontrar a melhor solução.

Contudo, caso o tomador de decisão, ao analisar informações que tem diante de si, deseje chegar a um resultado que confirme sua crença, fará a tentativa de construir uma justificativa, convincente primeiro a si próprio, e passível de persuadir terceiros. Assim, a pessoa, mesmo agindo sob a influência de um claro viés motivacional, mantém a "ilusão de objetividade" do seu próprio raciocínio. Quanto mais for competente em construir justificativas, mais estará sujeito a acreditar nas suas próprias conclusões - ou, dito de outra forma, "as pessoas vão acreditar no que elas quiserem apenas na medida em que sua razão permita." ${ }^{4}$

Uma das consequências práticas da teoria do Raciocínio Motivado é de que é possível influenciar os tomadores de decisão a adotarem a motivação por uma resposta mais precisa, em vez de uma resposta que confirme suas preconcepções - o que seria um possível caminho para reduzir a influência de vieses. Porém, o mais relevante para a presente discussão é que o modelo de Ziva Kunda incorpora ao "processo da descoberta" (a busca por informações para formar a própria convicção) o "processo da justificação": caso a motivação do raciocínio seja a de confirmar as próprias crenças, o indivíduo sente a necessidade de construir uma narrativa coerente e defensável do que acredita.

Uma segunda proposta, que igualmente articula a questão das intuições e da necessidade de justificá-las, é o modelo "social-intuicionista" de Jonathan Haidt, estudioso da Psicologia Moral. De acordo com esse modelo, as intuições precedem as justificativas; porém, uma vez que o tomador de decisão tem uma intuição sobre a resposta correta, trata de avaliá-la e de buscar razões que a justifiquem. Nesse processo, as opiniões dos seus pares importam: caso seja incapaz de justificar sua escolha perante os demais, o sujeito pode revisá-la. $\mathrm{O}$ processo social de justificação das decisões é, assim, um constrangimento para o processo de descoberta. Haidt utiliza a analogia de um porta-voz de uma organização: o presidente toma decisões, por motivos legítimos ou escusos; razoáveis, ou equivocados - não importa. A função do porta-voz é, mesmo sem ter acesso aos reais motivos da decisão, encontrar os argumentos mais persuasivos possíveis para apresentá-la ao público. Em suma, o raciocínio é, também, condicionado pelas intuições e justificativas disseminadas e defendidas no círculo social do tomador de decisão. ${ }^{45}$

Noel Struchiner e Marcelo Brando sugerem que, ao menos nos "casos difíceis", o modelo social-intuicionista do raciocínio moral de Haidt permite descrever o que ocorre na mente do juiz:

Tomando-se a descrição do processo de julgamento moral sugerido pelo modelo sócio-intuicionista, é possível formular a hipótese de que as decisões judiciais nesses casos são tomadas da seguinte forma: ao se depararem com os elementos 
de uma demanda moralmente carregada, os juízes veriam surgir na consciência, ou na margem da consciência, um sentimento avaliativo sobre o caso como um todo, sem qualquer consciência de se ter passado pelas etapas de busca e balanceamento de evidências, ou pela inferência controlada de uma conclusão. Esse flash de intuição causaria a experiência na consciência de uma condenação ou condecoração de uma das partes incluindo uma crença na correção ou incorreção da decisão. Esse é o julgamento moral. Tudo acontece de maneira rápida e automática, precedendo à consulta dos materiais jurídicos. (...) Uma vez tomada a decisão, o juiz sabe que não pode justificá-la para seus pares ou para a comunidade afirmando que um flash intuitivo e inconsciente o levou a tomar a decisão a favor ou contra as partes. A Constituição brasileira exige que o juiz apresente fundamentação construída a partir de materiais jurídicos existentes (art. 93, inciso IX). Portanto, a partir do momento em que o juiz ganha consciência da decisão moral e crê na sua correção, ele se vê diante da necessidade de justificá-la. O segundo elo do modelo sócio-intuicionista sugere que os realistas jurídicos também neste ponto estavam certos: os materiais jurídicos aparecem nas sentenças como parte de racionalizações post hoc de decisões tomadas com base em outros elementos. ${ }^{46}$

Por fim, a formulação teórica que recentemente mais tem ganhado atenção é a "Teoria Argumentativa do Raciocínio", formulada por Hugo Mercier e Dan Sperber. Os autores propõem que, em vez de pensarmos que a argumentação advém do raciocínio, devemos encarar a principal função do raciocínio como argumentativa, isto é, os seres humanos raciocinam sobre problemas por meio da necessidade da produção de justificativas. Encontrando bons argumentos para defender seu ponto de vista, as pessoas não se dão ao trabalho de se engajar em exaustivos raciocínios deliberativos, porém, caso precisem justificar seu ponto de vista diante de uma audiência, isso as obriga a refletir mais e a produzir melhores argumentos. Em caso de discordâncias de opinião, as pessoas tendem a ser muito vigilantes em relação a argumentos contrários aos seus, buscando contestá-los - e, caso não encontrem argumentos suficientes em defesa de sua posição, e tenham motivos para ter credibilidade no interlocutor, podem mudar de ideia. Assim, discussões de grupo podem ser efetivas quando os seus membros estiverem efetivamente engajados em encontrar a resposta correta para um problema. A Teoria Argumentativa do Raciocínio integra em um só marco teórico os achados da literatura psicológica recente e ajuda a explicar diversos vieses no raciocínio, como a dissonância cognitiva, o viés de confirmação e o raciocínio motivado. ${ }^{47} \mathrm{E}$, do ponto de vista da presente discussão, sugere que a existência de contextos de justificação mais exigentes pode levar a processos de descoberta mais rigorosos e menos enviesados.

Diante disso, a descrição que emerge da mecânica entre, de um lado, a produção de justificações para a decisão; e, de outro, os processos de descoberta, mesmo quando intuitivos ou enviesados, é a de que a argumentação pode servir de constrangimento ao raciocínio. Quanto menos exigentes os interlocutores ou os auditórios, menos incentivos o sujeito tem para tomar uma decisão cuidadosa. As teorias psicológicas da decisão, assim, mesmo quando evidenciam as "irracionalidades" e influências exógenas no processo de 
tomada de decisão, indicam que há constrangimentos que podem direcioná-lo rumo aos parâmetros esperados.

\section{DAS TEORIAS DA INTERPRETAÇÃO À TEORIA DA DECISÃO}

A objeção mais comum a abordagens realistas da decisão judicial é que elas abririam espaço para o decisionismo e o arbítrio, considerando como válidas ou aceitáveis quaisquer decisões, uma vez que não haveria um parâmetro "racional" de aceitabilidade e adequação dessas respostas. Essa acusação, porém, não procede, especialmente tendo em vista os modelos discutidos, em que os aspectos cognitivos ou intuitivos do processo de decisão não estão dissociados da justificação argumentativo-discursiva.

Um dos primeiros aspectos que precisam ser esclarecidos para que uma teoria da decisão mais abrangente seja formulada é a inutilidade de uma oposição rígida entre essas duas dimensões. Brian Tamanaha critica as divisões entre um "legalismo" segundo o qual a decisão é uma questão estritamente jurídica, e uma visão "realista" segundo a qual fatores sociais, psicológicos e políticos são os únicos determinantes. Em vez disso, propõe um "realismo balanceado", que combine:

Por um lado, à consciência das falhas, limitações e da abertura do Direito, a consciência de que juízes às vezes fazem escolhas, que podem manipular regras e precedentes jurisprudenciais, que às vezes são influenciados por visões políticas e morais e por seus vieses pessoais (aspecto cético). Por outro lado, um ceticismo que compreende que regras jurídicas funcionam apesar disso; que juízes cumprem e aplicam o Direito; que há fatores práticos, sociais e institucionais que constrangem os juízes; e que juízes proferem decisões geralmente previsíveis, coerentes com o Direito (aspecto guiado pelas regras) ${ }^{48}$.

Em sentido semelhante, Bruce Anderson nos convida a deixar de lado as oposições excludentes entre os processos de descoberta e justificação da decisão judicial:

Descrições do raciocínio jurídico nem sempre foram dominados por análises restritas à justificação. Juristas nem sempre presumiram haver uma divisão "rígida" entre descoberta e justificação. E nem sempre sustentaram que o "verdadeiro" processo que leva um juiz a uma decisão é desimportante, arbitrário ou irracional, ou ainda que não poderia ou deveria ser estudado pelos juristas. Para expoentes do Realismo Jurídico Americano (...), o processo de julgamento incluía tanto a operação mental de pensar (descobrir e testar soluções possíveis para um caso), quanto as exposições orais ou escritas que expõem seu resultado. Contrastando com os debates contemporâneos, na opinião desses realistas, as atividades mentais que precedem a exposição ou justificação de uma decisão são uma parte significativa dela. Embora destacassem o caráter não-lógico e não-racional das intuições judiciais, estas não eram apresentadas como atos arbitrários ou irracionais de descoberta ou invenção. ${ }^{49}$ 
Nesse sentido, Luiz Silveira propõe que se abandone a visão simplista da decisão judicial segundo a qual um momento de descoberta seja seguido por justificações a posteriori. Na sua proposta, descoberta e justificação da decisão judicial se articulam de forma dinâmica. Ao deparar com um caso, inicia-se o processo de descoberta do magistrado, em que intuições podem ter um papel importante. Porém, o processo de descoberta inclui a necessidade de justificação: o juiz precisa primeiro convencer a si mesmo de que a escolha que intuiu faz sentido. Para tanto, reúne argumentos que articulem juízos de valor que permitem defender sua escolha como jurídica, justa ou razoável. Por sua vez, ao reunir essas razões, o processo de descoberta é enriquecido, na medida em que a resposta inicialmente contemplada pode ser reforçada - ou abandonada, caso não seja suficientemente convincente. Assim, mesmo que um insight seja potencialmente irracional, ou enviesado, o processo de descoberta inclui um processo consciente de avaliação de razões e argumentos que o retroalimenta. ${ }^{50}$ Como se pode observar, essa proposta para a compreensão da decisão judicial está em sintonia com as teorias psicológicas da justificação analisadas na seção anterior.

Assim, adotar uma teoria da interpretação que leve em conta os elementos psicológicos envolvidos no processo decisório não significa ceder a aspectos "irracionais", imprevisíveis ou insondáveis da mente judicial. Pelo contrário, significa levar em conta uma gama de fatores que vinha sendo deixada de lado nos debates jurídico-filosóficos, analisando não só a força dos argumentos por si, mas também as audiências a que se referem, ou, ainda, os possíveis ganhos estratégicos ou reputacionais para o magistrado que os profere diante de públicos específicos, por um lado, e o ônus de sustentar decisões que contrariem setores relevantes para ele, por outro. Assim, justificação e descoberta são duas faces da mesma moeda, e a separação desses dois elementos é tão artificial e improdutiva quanto a desacreditada distinção entre interpretação e aplicação do Direito. Com isso, permite-se deslocar a discussão, hoje concentrada apenas nos métodos mais ou menos adequados para a justificação "racional" de uma decisão, e, sem retirar a importância dispensada à esfera discursiva, incorporar a ela o caráter inevitavelmente político-estratégico da atividade judicante..$^{51}$

\section{CONCLUSÃO}

Com base em um panorama das pesquisas empíricas sobre a decisão judicial, bem como nas teorias mais recentes sobre como a justificação argumentativa se articula com fins estratégicos no contexto social, buscamos mostrar que a oposição entre processos de descoberta e o contexto de justificação das decisões judiciais precisa ser superada.

Os estudos revisados sugerem que uma descrição do processo de tomada de decisão judicial deve levar em conta as influências extrajurídicas, que incluem as limitações cognitivas, as intuições, as preferências estratégicas e os auditórios específicos a que se dirige o magistrado. Quanto maior a margem de discricionariedade, maior a influência desses fatores. Assim, especialmente nos chamados "casos difíceis", em casos moralmente carregados, ou em julgamentos que envolvam o autointeresse dos próprios magistrados, ou suas preferências 
político-ideológicas, os fatores extrajurídicos devem ser levados em conta como influências que, sem a contraposição de constrangimentos institucionais e estratégicos dos demais atores envolvidos, podem ser determinantes no resultado da lide.

Contudo, os estudos também mostram que a justificação pode atuar como um constrangimento, na medida em que retroalimenta o processo de descoberta. Essa descrição sugere que se os interlocutores relevantes para o magistrado são mais exigentes e potencialmente discordam de sua opinião, o ônus decisório é maior, o que pode levar a decisões mais refletidas. Observa-se, assim, que, longe de trazer um mero ceticismo quanto ao valor da argumentação jurídica, uma perspectiva realista da interpretação permite vislumbrar que, em certos casos, a necessidade de justificação pode valer como um constrangimento estratégico na arena decisória.

Essa abordagem permite, assim, a elaboração de análises que escapam às teorias exclusivamente focadas sobre o contexto da justificação. De um lado, a dos casos fáceis ou corriqueiros, em que os juízes, premidos pelo volume de trabalho, efetivamente se valem de heurísticas para simplificar a análise processual, e não de uma análise abrangente dos fatos e textos jurídicos; de outro, a dos casos difíceis, em que não é a escolha do método hermenêutico que condiciona a decisão política, mas muito provavelmente o inverso o que ocorre.

Apontamos, por fim, que, contrariamente a teses correntes na discussão contemporânea, adotar uma teoria realista da interpretação não significa ceder espaço ao decisionismo, nem tampouco desconsiderar a força dos argumentos empregados na defesa de teses jurídicas. Pelo contrário, uma perspectiva realista permite que elementos estratégicos, reputacionais e psicológicos sejam igualmente analisados, em íntima relação com a produção discursiva, o que permite que se vislumbre a formulação de uma teoria integrada da decisão judicial.

\section{REFERÊNCIAS}

ANDERSON, Bruce. "Discovery” in legal decision-making. London: Kluwer Academic Publishers, 1996.

ARAÚJO, Mateus Morais. Comportamento estratégico no Supremo Tribunal Federal. 2017. Tese (Doutorado em Ciência Política), Universidade Federal de Minas Gerais, Belo Horizonte, 2017.

ARGUELHES, Diego Werneck; RIBEIRO, Leandro Molhano. O Supremo individual: mecanismos de atuação direta dos Ministros sobre o processo político. Direito, Estado e Sociedade, Rio de Janeiro, n. 46, p. 121-155, jan./jun. 2015.

ARISTÓTELES. Ética a Nicômacos. 2. ed. Brasília: UnB, 1992.

BAUM, Lawrence. Judges and their audiences. Princeton: Princeton University Press, 2006. BENFORADO, Adam. Unfair: the new science of criminal injustice. New York: Crown Publishers, 2015. 
BENVINDO, Juliano Zaiden; COSTA, Alexandre Araújo. A quem interessa o controle concentrado de constitucionalidade? o descompasso entre teoria e prática na defesa dos direitos fundamentais. 2013. Disponível em: < https://goo.gl/13ktUk>. Acesso em: 31 mar. 2017.

BRAMAN, Eileen. Searching for constraint in legal decision making. In: KLEIN, David; MITCHELL, Gregory. The psychology of judicial decision making. London: Oxford University Press, 2010.

CALAMANDREI, Piero. Eles, os juízes, vistos por um advogado. São Paulo: Martins Fontes, 1995.

COSTA, Alexandre A. Direito e método: diálogos entre a hermenêutica filosófica e a hermenêutica jurídica. 2008. 421 f. Tese (Doutorado em Direito) - Universidade de Brasília, Brasília, 2008.

COSTA, Alexandre A. Judiciário e interpretação: entre política e direito. Pensar (UNIFOR), Fortaleza, v. 18.1, p. 41-43, 2013.

COSTA, Eduardo José da Fonseca. Levando a imparcialidade a sério: proposta de um modelo interseccional entre direito processual, economia e psicologia. 2016. $187 \mathrm{f}$. Tese (Doutorado em Direito) - Pontifícia Universidade Católica de São Paulo, São Paulo, 2016.

DANZIGER, Shai; LEVAV, Jonathan; AVNAIM-PESSO, Liora. Extraneous factors in judicial decisions. Proceedings of the National Academy of Sciences, v. 108, n. 17, p. 6889-6892, 2011.

DESPOSATO, Scott W.; INGRAM, Matthew C.; LANNES JUNIOR, Osmar P. Power, Composition, and decision making: the behavioral consequences of institutional reform on Brazil's Supremo Tribunal Federal. The Journal of Law, Economics, and Organization, v. 31, n. 3, p. 534-567, 2014.

DHAMI, Mandeep K. Psychological models of professional decision making. Psychological Science, United States, v. 14, n. 2, p. 175-180, 2003.

DWORKIN, Ronald. O império do direito. Tradução Jefferson Luiz Camargo. São Paulo: Martins Fontes, 1999.

EPSTEIN, Lee; KNIGHT, Jack. Reconsidering judicial preferences. Annual Review of Political Science, United States, v. 16, p. 11-31, 2013.

EPSTEIN, Lee; LANDES, William M.; POSNER, Richard A. The behavior of federal judges: a theoretical and empirical study of rational choice. Cambridge: Harvard University Press, 2013.

FURGESON, Joshua R.; BABCOCK, Linda; SHANE, Peter M. Behind the mask of method: political orientation and constitutional interpretive preferences. Law and Human Behavior, United States, v. 32, p. 502-510, 2008. 
GAROUPA, Nuno; GINSBURG, Tom. Judicial reputation: a comparative theory. Chicago: Chicago University Press, 2015.

GUTHRIE, Chris; RACHLINSKI, Jeffrey J; WISTRICH, Andrew J. Blinking on the bench: how judges decide cases. Cornell Law Review, United States, v. 93, p. 1-44, 2007.

HAIDT, Jonathan. Moral Psychology and the law: how intuitions drive reasoning, judgment and the search for evidence. Alabama Law Review, United States, v. 64, n. 4, p. 867-880, 2012. HARMON-JONES, Eddie; HARMON-JONES, Cindy. cognitive dissonance theory after 50 years of development. Zeitschrift für Sozialpsychologie, v. 38, n. 1, p. 7-16, 2007.

HESPANHA, António M. Panorama histórico da cultura jurídica Européia. Mem Martins: Europa-América, 1997.

HORTA, Ricardo de Lins e. Argumentação, estratégia e cognição: subsídios para a formulação de uma teoria da decisão judicial. Revista Eletrônica Direito e Liberdade, Natal, v. 18, p. 151-193, 2016.

JOLLS, Christine; SUNSTEIN, Cass R. Debiasing through Law. The Journal of Legal Studies, v. 35, n. 1, p. 199-242, 2006.

KAHAN, Dan M. et al. They saw a protest: cognitive illiberalism and the speech-conduct distinction. Stanford Law Review, United States, v. 64, n. 4, p. 851-906, 2012.

KAHNEMAN, Daniel. Rápido e devagar: duas formas de pensar. Rio de Janeiro: Objetiva, 2012. KELSEN, Hans. Teoria pura do direito. 3. ed. São Paulo: Martins Fontes, 1991.

KLEINBERG, Jon et al. Human decisions and machine predictions. NBER Working Paper n. 23180. 2017. Disponível em: <http://www.nber.org/papers/w23180>. Acesso em: 31 mar. 2017.

KUNDA, Ziva. The case for motivated reasoning. Psychological Buletin, v. 108, n. 3, p. 480-498, 1990.

LORD, Charles G.; ROSS, Lee; LEPPER, Mark R. Biased Assimilation and attitude polarization: the effects of prior theories on subsequently considered evidence. Journal of Personality and Social Psychology, United States, v. 37, n. 11, p. 2098-2109, 1979.

MACCORMICK, Neil. Argumentação jurídica e teoria do direito. Tradução Waldéa Barcellos. São Paulo: Martins Fontes, 2006.

MERCIER, Hugo. The argumentative theory: predictions and empirical evidence. Trends in Cognitive Sciences, United Kingdom,v. 20, n. 9, p. 689-700, Sept. 2016.

MERCIER, Hugo; SPERBER, Dan. Why do humans reason? arguments for an argumentative theory. Behavioral and Brain Sciences, United Kingdom, v. 34, p. 57-111, 2011.

MOLDEN, Daniel C.; HIGGINS, E. Tory. Motivated thinking. In: HOLYOAK, Keith J.; 
MORRISON, Robert G. The oxford handbook of thinking and reasoning. New York: Oxford University Press, 2012.

NICKERSON, Raymond S. Confirmation bias: a ubiquitous phenomenon in many Guises. Review of General Psychology, United States, v. 2, n. 2, p. 175-220, 1998.

PERELMAN, Chaïm. Lógica jurídica. São Paulo: Martins Fontes, 1998.

PI, Daniel; PARISI, Francesco; LUPPI, Barbara. Biasing, debiasing and the law. In: TEICHMAN, Doron; ZAMIR, Eyal. Behavioral economics and the law. Oxford: Oxford University Press, 2014.

POSNER, Richard A. What do judges and justices maximize? the same things everyone else does. Supreme Court Economic Review, v. 3, p. 1-41, 1993.

POSNER, Richard A. How judges think. Cambridge: Harvard University Press, 2008.

RODRIGUEZ, José Rodrigo. Como decidem as cortes? para uma crítica do direito (brasileiro). Rio de Janeiro: Editora GV, 2013.

SCHAUER, Frederick. Incentives, Reputation, and the inglorious determinants of judicial behavior. University of Cincinnati Law Review, United States, v. 68, p. 615-636, 2000.

SILVEIRA, Luiz Fernando Castilhos. Discovery and justification of judicial decisions: towards more precise distinctions in legal decision-making. Recht en Methode in onderzoek en onderwijs, v. 2014-9, 2014.

SPAMANN, Holger; KLÖHN, Lars. Justice is less blind, and less legalistic, than we thought: evidence from an experiment with real judges. The Journal of Legal Studies, v. 45, n. 2, p. 255-280, 2016.

STRUCHINER, Noel; BRANDO, Marcelo S. Como os juízes decidem os casos difíceis do direito? In: STRUCHINER, Noel; TAVARES, Rodrigo de Souza. Novas fronteiras da teoria do direito: da filosofia moral à psicologia experimental. Rio de Janeiro: PUC-Rio, 2014.

SUNSTEIN, Cass et al. Are judges political? an empirical analysis of the federal judiciary. Washington: Brookings Institution Press, 2006.

TAMANAHA, Brian Z. Beyond the formalist-realist divide: the role of politics in judging. Princeton: Princeton University Press, 2010.

TEICHMAN, Doron; ZAMIR, Eyal. Judicial decision-making: a behavioral perspective. In: TEICHMAN, Doron; ZAMIR, Eyal. Behavioral economics and the law. Oxford: Oxford University Press, 2014.

1 ARISTÓTELES. Ética a Nicômacos. 2. ed. Brasília: UnB, 1992. Livro V.

2 COSTA, Alexandre A. Direito e método: diálogos entre a hermenêutica filosófica e a hermenêutica jurídica. 2008. 421 f. Tese (Doutorado em Direito) - Universidade de Brasília, Brasília, 2008. p. 21-26.

3 COSTA, Alexandre A. Direito e método: diálogos entre a hermenêutica filosófica e a hermenêutica jurídica. 2008. 421 f. Tese (Doutorado em Direito) - Universidade de Brasília, Brasília, 2008. p. 54-71. 
4 HESPANHA, António M. Panorama histórico da cultura jurídica Européia. Mem Martins: Europa-América, 1997. p. 177.

5 COSTA, Alexandre A. Direito e método: diálogos entre a hermenêutica filosófica e a hermenêutica jurídica. 2008. 421 f. Tese (Doutorado em Direito) - Universidade de Brasília, Brasília, 2008. p. 87.

6 KELSEN, Hans. Teoria pura do direito. 3. ed. São Paulo: Martins Fontes, 1991. p. 366-371.

7 COSTA, Alexandre A. Direito e método: diálogos entre a hermenêutica filosófica e a hermenêutica jurídica. 2008. 421 f. Tese (Doutorado em Direito) - Universidade de Brasília, Brasília, 2008. p. 341-359.

8 PERELMAN, Chaïm. Lógica jurídica. São Paulo: Martins Fontes, 1998. p. 137.

9 CALAMANDREI, Piero. Eles, os juízes, vistos por um advogado. São Paulo: Martins Fontes, 1995. p. 176.

10 MACCORMICK, Neil. Argumentação jurídica e teoria do direito. Tradução Waldéa Barcellos. São Paulo: Martins Fontes, 2006. p. 19-20.

11 EPSTEIN, Lee; KNIGHT, Jack. Reconsidering judicial preferences. Annual Review of Political Science, United States, v. 16, p. 11-31, 2013. p. 14.

12 TAMANAHA, Brian Z. Beyond the formalist-realist divide: the role of politics in judging. Princeton: Princeton University Press, 2010. p.111-121.

13 POSNER, Richard A. What do judges and justices maximize? the same things everyone else does. Supreme Court Economic Review, v. 3, p. 1-41, 1993. p. 3-21.

14 SCHAUER, Frederick. Incentives, Reputation, and the inglorious determinants of judicial behavior. University of Cincinnati Law Review, United States, v. 68, p. 615-636, 2000. p. 623. Tradução livre.

15 EPSTEIN, Lee; KNIGHT, Jack. Reconsidering judicial preferences. Annual Review of Political Science, v. 16. p. 15-26, 2013. Ver também: POSNER, Richard A. How judges think. Cambridge: Harvard University Press, 2008.

16 EPSTEIN, Lee; LANDES, William M.; POSNER, Richard A. The behavior of federal judges: a theoretical and empirical study of rational choice. Cambridge: Harvard University Press, 2013. p. 65-89. Ver também: SUNSTEIN, Cass et al. Are judges political? an empirical analysis of the federal judiciary. Washington: Brookings Institution Press, 2006.

17 EPSTEIN, Lee; LANDES, William M.; POSNER, Richard A. The behavior of federal judges: a theoretical and empirical study of rational choice. Cambridge: Harvard University Press, 2013. p. 126-136.

18 GAROUPA, Nuno; GINSBURG, Tom. Judicial reputation: a comparative theory. Chicago: Chicago University Press, 2015. p. 19.

19 GAROUPA, Nuno; GINSBURG, Tom. Judicial reputation: a comparative theory. Chicago: Chicago University Press, 2015. p. 147-148. A prática de valorizar os votos individuais de magistrados, em detrimento da redação de votos coletivos, os quais contemplam a maioria formada no colegiado é um traço da forma como decidem as cortes superiores brasileiras, notadamente o STF, como mostrou José Rodrigo Rodriguez. Utilizando o modelo de Garoupa \& Ginsburg, pode-se sugerir que, em detrimento da inteligibilidade da jurisprudência, esse modelo favorece a reputação individual dos Ministros. Vide RODRIGUEZ, José Rodrigo. Como decidem as cortes? para uma crítica do direito (brasileiro). Rio de Janeiro: Editora GV, 2013.

20 EPSTEIN, Lee; LANDES, William M.; POSNER, Richard A. The behavior of federal judges: a theoretical and empirical study of rational choice. Cambridge: Harvard University Press, 2013. p. 154-199; 235-241; 385-395.

21 DESPOSATO, Scott W.; INGRAM, Matthew C.; LANNES JUNIOR, Osmar P. Power, Composition, and decision making: the behavioral consequences of institutional reform on Brazil's Supremo Tribunal Federal. The Journal of Law, Economics, and Organization, v. 31, n. 3, p. 534-567, 2014.

22 BENVINDO, Juliano Zaiden; COSTA, Alexandre Araújo. A quem interessa o controle concentrado de constitucionalidade? o descompasso entre teoria e prática na defesa dos direitos fundamentais. 2013. (Relatório de pesquisa).

23 ARAÚJO, Mateus Morais. Comportamento estratégico no Supremo Tribunal Federal. 2017. Tese (Doutorado em Ciência Política), Universidade Federal de Minas Gerais, Belo Horizonte, 2017.

24 ARGUELHES, Diego Werneck; RIBEIRO, Leandro Molhano. O Supremo individual: mecanismos de atuação direta dos Ministros sobre o processo político. Direito, Estado e Sociedade, Rio de Janeiro, n. 46, p. 121-155, jan.jun. 2015.

25 "Alguns realistas exprimiram essas ideias em uma linguagem profundamente cética. Afirmaram que o direito não existe, diziam, ou o direito não passa da previsão do que farão os tribunais, ou é apenas uma questão daquilo que os juízes tomaram no café da manhã”. DWORKIN, Ronald. O império do direito. Tradução Jefferson Luiz Camargo. São Paulo: Martins Fontes, 1999. p. 45. 
26 DANZIGER, Shai; LEVAV, Jonathan; AVNAIM-PESSO, Liora. Extraneous factors in judicial decisions. Proceedings of the National Academy of Sciences, v. 108, n. 17, p. 6889-6892, 2011.

27 KAHNEMAN, Daniel. Rápido e devagar: duas formas de pensar. Rio de Janeiro: Objetiva, 2012.

28 DHAMI, Mandeep K. Psychological models of professional decision making. Psychological Science, United States, v. 14, n. 2, p. 175-180, 2003.

29 GUTHRIE, Chris; RACHLINSKI, Jeffrey J; WISTRICH, Andrew J. Blinking on the bench: how judges decide cases. Cornell Law Review, United States, v. 93, p. 1-44, 2007.

30 SPAMANN, Holger; KLÖHN, Lars. Justice is less blind, and less legalistic, than we thought: evidence from an experiment with real judges. The Journal of Legal Studies, v. 45, n. 2, p. 255-280, 2016.

31 Para uma revisão dos estudos sobre heurísticas e vieses no contexto judicial, vide TEICHMAN, Doron; ZAMIR, Eyal. Judicial decision-making: a behavioral perspective. In: TEICHMAN, Doron; ZAMIR, Eyal. Behavioral economics and the law. Oxford: Oxford University Press, 2014.

32 KAHAN, Dan M. et al. They saw a protest: cognitive illiberalism and the speech-conduct distinction. Stanford Law Review, United States, v. 64, n. 4, p. 851-906, 2012.

33 FURGESON, Joshua R.; BABCOCK, Linda; SHANE, Peter M. Behind the mask of method: political orientation and constitutional interpretive preferences. Law and Human Behavior, United States, v. 32, p. 502-510, 2008.

34 BAUM, Lawrence. Judges and their audiences. Princeton: Princeton University Press, 2006.

35 BRAMAN, Eileen. Searching for constraint in legal decision making. In: KLEIN, David; MITCHELL, Gregory. The psychology of judicial decision making. London: Oxford University Press, 2010.

36 JOLLS, Christine; SUNSTEIN, Cass R. Debiasing through Law. The Journal of Legal Studies, v. 35, n. 1, p. 199-242, 2006. Para um texto mais recente, incorporando vários trabalhos publicados nos últimos anos, vide PI, Daniel; PARISI, Francesco; LUPPI, Barbara. Biasing, debiasing and the law. In: TEICHMAN, Doron; ZAMIR, Eyal. Behavioral economics and the law. Oxford: Oxford University Press, 2014. Para uma perspectiva do sistema de Justiça brasileiro, vide COSTA, Eduardo José da Fonseca. Levando a imparcialidade a sério: proposta de um modelo interseccional entre direito processual, economia e psicologia. 2016. 187 f. Tese (Doutorado em Direito) Pontifícia Universidade Católica de São Paulo, São Paulo, 2016.

37 Esse é um argumento tratado de forma especialmente enfática em BENFORADO, Adam. Unfair: the new science of criminal injustice. New York: Crown Publishers, 2015.

38 Vide KLEINBERG, Jon et al. Human decisions and machine predictions. NBER Working Paper n. 23180. 2017. Disponível em: <http://www.nber.org/papers/w23180>.

39 Vide HORTA, Ricardo de Lins e. Argumentação, estratégia e cognição: subsídios para a formulação de uma teoria da decisão judicial. Revista Eletrônica Direito e Liberdade, v. 18, p. 151-193, 2016.

40 LORD, Charles G.; ROSS, Lee; LEPPER, Mark R. Biased Assimilation and attitude polarization: the effects of prior theories on subsequently considered evidence. Journal of Personality and Social Psychology, United States, v. 37, n. 11, p. 2098-2109, 1979.

41 HARMON-JONES, Eddie; HARMON-JONES, Cindy. cognitive dissonance theory after 50 years of development. Zeitschrift für Sozialpsychologie, v. 38, n. 1, p. 7-16, 2007. p. 7-9.

42 NICKERSON, Raymond S. Confirmation bias: a ubiquitous phenomenon in many Guises. Review of General Psychology, United States, v. 2, n. 2, p. 175-220, 1998.

43 Para uma revisão recente dessa literatura, vide MOLDEN, Daniel C.; HIGGINS, E. Tory. Motivated thinking. In: HOLYOAK, Keith J.; MORRISON, Robert G. The oxford handbook of thinking and reasoning. New York: Oxford University Press, 2012.

44 KUNDA, Ziva. The case for motivated reasoning. Psychological Buletin, v. 108, n. 3, p. 480-498, 1990. p. 483.

45 HAIDT, Jonathan. Moral Psychology and the law: how intuitions drive reasoning, judgment and the search for evidence. Alabama Law Review, United States, v. 64, n. 4, p. 867-880, 2012.

46 STRUCHINER, Noel; BRANDO, Marcelo S. Como os juízes decidem os casos difíceis do direito? In: STRUCHINER, Noel; TAVARES, Rodrigo de Souza. Novas fronteiras da teoria do direito: da filosofia moral à psicologia experimental. Rio de Janeiro: PUC-Rio, 2014. p. 199-200.

47 MERCIER, Hugo; SPERBER, Dan. why do humans reason? arguments for an argumentative theory. Behavioral and Brain Sciences, v. 34, p. 72, 2011. MERCIER, Hugo. The argumentative theory: predictions and empirical evidence. Trends in Cognitive Sciences, United Kingdom,v. 20, n. 9, p. 689-700, Sept. 2016. 
48 TAMANAHA, Brian Z. Beyond the formalist-realist divide: the role of politics in judging. Princeton: Princeton University Press, 2010.p. 6. Tradução livre.

49 ANDERSON, Bruce. "Discovery” in legal decision-making. London: Kluwer Academic Publishers, 1996. p. 2

50 SILVEIRA, Luiz Fernando Castilhos. Discovery and justification of judicial decisions: towards more precise distinctions in legal decision-making. Recht en Methode in onderzoek en onderwijs, v. 2014-9, 2014.

51 COSTA, Alexandre A. Judiciário e interpretação: entre política e direito. Pensar (UNIFOR), Fortaleza, v. 18.1, p. 41-43, 2013.

\title{
FROM INTERPRETATION THEORIES TO DECISION THEORY: ON A REALISTIC PERSPECTIVE ABOUT INFLUENCES AND CONSTRAINTS IN JUDICIAL DECISION-MAKING
}

\begin{abstract}
The idea that it is possible to develop an interpretative method that leads to right answers is still paramount in contemporary jurisprudence, especially in the Theory of Legal Argumentation. As a result, judicial behavior is relegated to a secondary role in the development of traditional theories. Descriptive research in this subject is often inspired by Legal Realism, which took determined the need for an Empirical Science of Law to be practiced, capable of explaining the role of political-ideological and personal preferences, among others, in judicial decision-making. In the present article, we claim that a realistic theory of interpretation, that treats Law as a decision arena, allows for a Theory of Decision-Making which integrates not only discourse, but also strategic, social and reputational factors. To this end, we present various empirical studies, from Cognitive and Social Psychology, Political Science and Behavioral Economics, that investigate how extraneous factors influence and constrain judicial decision-making. Moreover, we draw upon recent theories on how human reasoning relates to the production of justifications to argue that, in light of a Theory of Judicial Decision-Making, the opposition between "discovery" and "justification" should be abandoned.
\end{abstract}

Keywords: Judicial decision-making. Theory of Legal Argumentation. Discovery in decision-making. Extraneous factors in judicial decisions. Realism in legal interpretation.

Submetido: 31 mar. 2017

Aprovado: 31 maio 2017 